\title{
HNRNPAB wt Allele
}

National Cancer Institute

\section{Source}

National Cancer Institute. HNRNPAB wt Allele. NCI Thesaurus. Code C51248.

Human HNRNPAB wild-type allele is located in the vicinity of $5 q 35.3$ and is approximately

$7 \mathrm{~kb}$ in length. This allele, which encodes heterogeneous nuclear ribonucleoprotein $A / B$, plays a role in pre-mRNA processing and other aspects of mRNA metabolism and transport. 